\title{
Corporate governance and tax aggresiveness, an evidence on manufacturing companies in Indonesia
}

\author{
Ida Farida Adi Prawira* \\ Department of Accounting, Faculty of Economic and Business Education, Indonesia Education University \\ 229th Dr.Setiabudhi Street, Bandung, West Java, Indonesia 40154 \\ *Corresponding author E-mail: ida.farida@upi.edu
}

\begin{abstract}
The aim of this research is to find out about the influence of corporate governance (Size of Board Commissioners and size of directors) toward tax aggressiveness in manufacturing companies, which are listed in Indonesian Stock Exchange. The sample of this research was 58 manufacturing companies over three years is 2013-2015 with a total of 174 samples, using a purposive sampling method. In this research, researchers used documentation study to collected secondary data with web browsing. Data analysis was performed with the classical assumption and hypothesis testing with multiple linear regression method.To analyze data using SPSS software version 21. The results of hypothesis testing showed that have an influence among corporate governance (Size of Board Commissioners and size of directors) toward tax aggressiveness in manufacturing companies with an indicator books tax different.
\end{abstract}

Keywords: Corporate Governance; Tax Aggressiveness; Manufacturing Companies.

\section{Introduction}

The practice of tax avoidance is now a major problem throughout the world. Panama Papers shows how much potential tax avoidance that occurred including in Indonesia. Perhaps, a report called Panama Papers from the international Consortium of Investigative Journalists (ICIJ) is a frightening specter for world public official's politicians, super-rich and celebrities whose names are mentioned in the document (Sudiarta, 2016). Australia began an investigation of 800 companies and individuals whose names are included in the document. Likewise, other countries such as India, France, Italy, and New Zealand. In Indonesia, the Minister of Finance has requested the Directorate General of Taxes to study the document. Panama Papers data becomes additional information in testing compliance of tax payments, complementing data already owned by DGT, especially Taxpayer data that earn overseas income.

Due to the nature of tax evasion that does not violate regulations, the DGT cannot impose legal sanctions on companies, although this behavior will reduce the state revenue from the tax sector (Mangoting, 1999). While corporate tax evasion has an indirect effect on society, tax evasion firms give a bad impression because people perceive that this activity will limit the transfer of income to the wider community (Fuest and Riedel, 2009). Whereas according to the society, the company should participate in improving the welfare of the community through the payment of taxes (Prawira, 2016).

The condition of corporate governance turned out to affect the decisions taken company. In companies with poor governance, tax evasion activities are not valuable to shareholders, and even reduce the value of the company itself (Desai and Dharmapala, 2006; Wahab and Holland, 2012). Desai and Dharmapala (2006) show that companies with poor governance, when an increase in profits for managers (in the form of compensation), decreases tax avoidance, which should be done for shareholders. While companies with good governance turned out to have a higher level of tax avoidance

Corporate governance plays a role for the company to improve the company's performance. Implementation of corporate governance can encourage management to manage companies more efficiently and implement appropriate measures for the benefit of the company. This will affect the better internal control so that the entire management of the company will be more effective and efficient. Conflicts of interest that occur between principals, and agents can be addressed through good corporate governance as a mechanism used to control managers (Shleifer \& Vishny, 1997) the application of corporate governance principles is able to reduce aggressive tax action and aggressive financial reporting. Corporate governance is believed to be capable of limiting management space so that it will be difficult to take aggressive tax action and financial reporting simultaneously. Corporate governance policies can reduce the opportunistic actions of managers in maximizing their own interests.

The strong corporate governance of a company is determined by the size of the board of commissioners and the size of the board of directors (Minnick \& Noga, 2010). Board of commissioners is the core of corporate governance that is assigned to ensure the implementation of corporate strategy, supervise the management in managing the company, and oblige the implementation of accountability (Irawan \& Aria, 2012). Irawan \& Aria also stated that in addition to the board of commissioners in command of supervising, the board of directors of management plays an important role in choosing a strategy by the company to increase wealth. Management is obliged to utilize the company's resources efficiently and improve the company's performance so that the value of the company increases. One strategy that is done is with the efficiency of tax payments. Therefore, the indicators of corporate 
governance in this study are the size of the board of commissioners and the size of the board of directors within the company.

\section{Literature reviews}

Companies should be able to take advantage of the loopholes that exist in the tax laws. This action is often also called aggressive action in taxation. The definition of aggressive tax action is an act designed or manipulated to reduce fiscal profit through appropriate tax planning, which is not classified as tax evasion. Tax aggressiveness is also measured using the size of tax management, by calculating the ratio of a book tax differences (Hanlon \& Slemrod, 2009). The result of tax management is the real amount of tax paid by the company listed in the income statement of the company (Frank et al., 2012).

The literature on the influence of corporate governance on tax aggressiveness has been found. Among them by Armstrong et al. (2012), which conducts research on the compensation relationships received by corporate executives, in particular, on compensation received by the tax director, of corporate tax management. In the study, they used two types of proxy for executive compensation. The first proxy is the total value of compensation received by the executive for a year. The second proxy is the compensation mix, ie the ratio of each component of the executive compensation to the total compensation received. They attest to a strong negative relationship between compensation received by the company's tax director with corporate tax payments as measured by the effective tax rate GAAP

Minnick and Noga (2010) also conducted research on the effects of management compensation on tax management, which found the effects of stock-based compensation packages, as one component of corporate governance, encouraged managers to manage taxes for the efficiency of corporate tax payments. It can add value from the company and give the benefit to the shareholders because it is positively related to the high rate of return to them. In his research, Minnick and Noga (2010) used the composition of directors, entrenchment, board compensation, and executive compensation as a proxy for corporate governance mechanisms.

In a study conducted by Noor et al. (2010) in companies in Malaysia by using the dependent variable in the form of an effective tax rates. The independent variables used by Noor et al. Ie firm size, return on asset (ROA), corporate debt, fixed asset intensity, inventory intensity, business differences, different taxation methods and different taxes. The result of the research is that firm size and inventory intensity have positive effect to the effective tax rate. For the ROA variable, corporate debt and fixed asset, intensity negatively affected the effective tax rate. For the business type of the company obtained the result that the product industry, trade and services, consumer products, agriculture, technology and property have a lower effective tax rate than other sectors.

Bernard (2011) in his research-related tax management using the characteristics of corporate governance and compensation as an independent variable. The results from his research found a positive relationship between the number of boards of commissioners with tax management and a significantly negative relationship between the proportion of an independent board of commissioners and compensation with tax management. Tax management is measured using the ETR indicator.

Irawan and Aria (2012) in his research entitled The Effect of Management Compensation and Corporate Governance on Corporate Tax Management. Finding a positive and significant relationship between corporate governance and CETR compensation. The research combines research conducted by Minnick and Noga (2010) and Armstrong et al. (2012).

Sabli and Noor (2012) found that internal and external corporate governance mechanisms do not affect the company's effective tax rate. The independent variables used in this study are proportion of independent directors and institutional investors while the control variables used are firm size, leverage, return on asset and capital intensity ratio. The results of this study indicate that the company still has a high dependence on tax consultant assistance rather than top management in activity planning activities.

In 2015, Novriansyah Zulkarnaen conducted a study on the influence of corporate governance on tax management. Corporate governance such as independent commissioners, exclusive management compensation and institutional investors. The results of this study are independent commissioners, exclusive management compensation and institutional investors partially and silmultan influence on tax management.

Rashid, Noor, Mastuki \& Bardai conduct research under the title Longitudinal Study of Corporate Tax Planning: Analysis on Companies' Tax Expense and Financial Ratios in year2015. Independent variables in this research are inventory intensity, capital intensity, research and development of intensity profitability, leverage. Dependent variable in this research is tax planning. By using multiple linear regression analysis, the result of this research is inventory intensity, capital intensity, research and development intensity; profitability (ROA) and leverage have significant relationship and negative relation with tax planning strategy (ETR).

\section{Methodology}

This study uses descriptive research method, which examines in depth and thoroughly so as to illustrate how the influence of corporate governance to tax aggressiveness. Increase in taxation cases up to 280 percent from 2013 to 2014 occurs dominated by manufacturing companies (Kristiyono, 2015), so the study population is 146 manufacturing companies listed on the Indonesia Stock Exchange. Data used in the form of financial statements of 2013, 2014, and 2015. Corporate governance is assessed by using the number of boards of commissioners with the number of boards of directors, while tax aggressiveness assessed by book tax difference (BTD). Data is processed by using linear regression.

\section{Results and discussion}

Based on the data of the company's annual report for the period of 2013-2015, the following describes the results of the board of commissioner size and board size data of 58 companies in the manufacturing sector listed on the BEI using the maximum value analysis method, the minimum value, and the mean value (mean).

Table 1: Descriptive Statistics of Corporate Governance Year 2013-2015

\begin{tabular}{|c|c|c|c|c|c|c|c|c|}
\hline \multirow{2}{*}{ No } & \multirow{2}{*}{ Kode } & \multirow[b]{2}{*}{ Nama Perusahaan } & \multicolumn{3}{|c|}{ Dewan Komisaris } & \multicolumn{3}{|c|}{ Dewan Direksi } \\
\hline & & & 2013 & 2014 & 2015 & 2013 & 2014 & 2015 \\
\hline 1 & AGII & Aneka Gas Industri Tbk. & 6 & 6 & 8 & 5 & 5 & 6 \\
\hline 2 & ALDO & Alkindo Naratama Tbk. & 3 & 3 & 3 & 3 & 3 & 3 \\
\hline 3 & AMFG & Asahimas Flat Glass Tbk. & 11 & 11 & 11 & 6 & 6 & 6 \\
\hline 4 & APLI & Asiaplast Industries Tbk. & 3 & 3 & 3 & 3 & 3 & 3 \\
\hline 5 & BTON & Betonjaya Manunggal Tbk. & 3 & 3 & 3 & 2 & 2 & 2 \\
\hline 6 & CPIN & $\begin{array}{l}\text { Charoen Pokphand Indone- } \\
\text { sia Tbk }\end{array}$ & 7 & 7 & 7 & 6 & 6 & 5 \\
\hline 7 & DPNS & $\begin{array}{l}\text { Duta Pertiwi Nusantara } \\
\text { Tbk. }\end{array}$ & 4 & 4 & 4 & 3 & 3 & 3 \\
\hline 8 & EKAD & $\begin{array}{l}\text { Ekadharma International } \\
\text { Tbk. }\end{array}$ & 3 & 3 & 3 & 2 & 2 & 2 \\
\hline
\end{tabular}




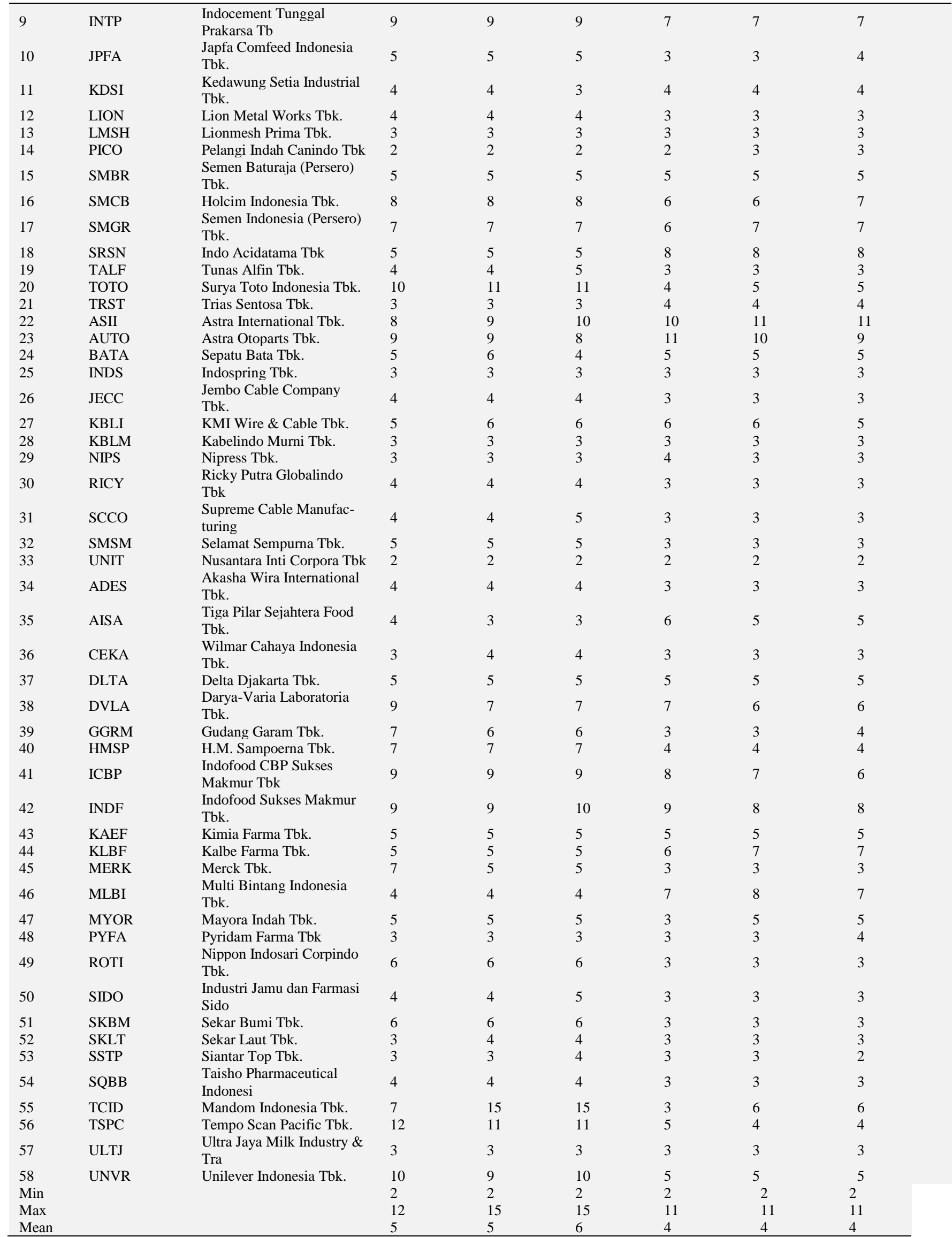

Source: company financial statements (data processed).

From the Table 1 above, it is seen that the calculation of the size of the board of commissioners and board of directors have almost the same value every year. The size of the board of commissioners at least from 2013 to 2015 is at PT. Nusantara Inti Corpora Tbk. And PT. Pelangi Indah Canindo Tbk. The two companies have 2 boards of commissioners. While the size of the largest board of commissioners in 2013 is at PT. Tempo Scan Pacific Tbk. A total of 12 people. In 2014 and 2015 PT. Mandom Indonesia Tbk. Has the largest board of commissioners as many as 15 people 
In 2013 and 2014 the average size of the board of commissioners is as many as 5 people. And in 2015 increased to 6 people. The size of the largest board of directors in 2013 is at PT. Astra Otoparts Tbk. As many as 11 people. In 2014 and 2015 the size of the largest board of directors is at PT. Astra International Tbk. As many as the previous year that is as many as 11 people. Meanwhile, the size of the board of directors in 2013-2015 at PT. Nusantara Inti Corpora Tbk, PT. Ekadharma International Tbk.dan PT. Betonjaya Manunggal Tbk. Has the smallest size that is as much as 2 people.In contrast to the size of the board of commissioners, the average size of the board of directors does not increase annually. The average size of the board of directors of 2013-2015 is the same as many as 4 people.

If viewed from year to year in 58 companies manufacturing sector in BEI period 2013-2015, the average size of board of commissioner and board size tends to be stable every year. This can be seen in Figure 4.3 below:

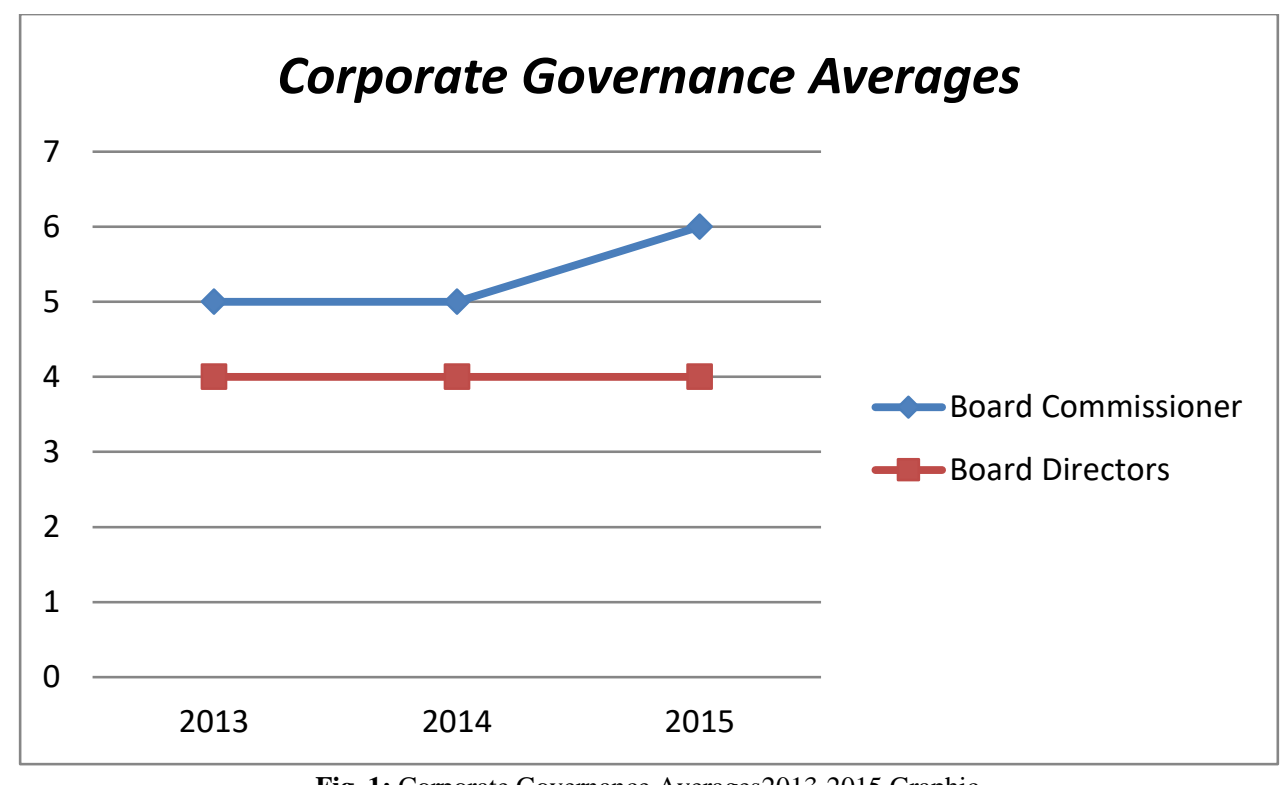

Fig. 1: Corporate Governance Averages2013-2015 Graphic.

Based on Figure 1. Shows the size of the board of commissioners in 2013 and 2014 did not increase, in both years the average size of the board of commissioners of 5 people. In 2015 the average size of the board of commissioners increased to 6 people, this year the average size of the highest commissioners compared with the previous year.In contrast to the size of the board of commissioners, the average size of the board of directors annually does not increase. In 2013-2015 the average size of the same board of directors as many as 4 people. This means that by 2015 it can be mentioned that corporate governance structure in the year is good compared to the previous year because it has a high board of commissioner size although the size of the board of directors in that year is the same as the previous year.

Tax aggressiveness is measured using Book Tax Different (BTD) The bigger the BTD, the bigger the company is tax aggresiveness. The calculation formulation is:

$$
\mathrm{BTD}=\frac{(\text { Commercial profit-Profit Fiscal })}{(\text { Total Asset })}
$$

Based on the data of the company's annual report for the period of 2013-2015, the following is a description of comparative data of tax aggresiveness with book tax different indicator on 58 firms in manufacturing sector listed on BEI using maximum value analysis method, minimum value and average value Mean).

From the Table 2. Above, it can be seen that the calculation of tax aggressiveness with Book Tax Different (BTD) is different. Based on Table2. above, shows the development of corporate tax aggresiveness megalami decreased every year. The average value of the highest different tax book is in the year 2013 at 0,03040 . While the average value of the lowest different tax book is in the year 2014 that is equal to 0.01995 .

In 2013, PT. Multi Bintang Indonesia Tbk. The highest tax aggressiveness, seen from the value of book tax different highest compared with other companies that is equal to 0.25679 . While the lowest value is in PT.KMI Wire \& Cable Tbk.yaitu of 0.02755 , which means that this year the company is not much to do tax aggresiveness, and the average value in this year amounted to 0.03040 .

In 2014, the highest different tax book is achieved by PT. Kalbe Farma Tbk. That is equal to 0,15478 . While the lowest value achieved by PT. Charoen Pokphand Indonesia Tbk. Ie -0.05332, and the average value in this year is 0,01995 .

In 2015, the highest different tax book is achieved by PT. Mandom Indonesia Tbk. Which is equal to 0.20632 , which means that this year the company is doing a high-tax aggressiveness, while the lowest value achieved by the company PT. Merck Tbk. Ie 0.04527 which means that this year the company is doing low tax aggressiveness, and the average value in this year is 0,02250 .

When viewed from year to year, the development of debt levels in the 58 companies in the manufacturing sector of BEI period 20132015 decreased from year to year. This can be seen in Figure 2. Below:

Based on Figure 1, the aggressiveness tax shows the period 20132015 fluctuated up and down each year. 2013 has the highest average tax aggressiveness compared to the following year at 0 , 03040. In 2014 it decreased to 0.01995 . In the year 2015 has increased again to be 0,02250 . This means that in 2013 the company's aggressiveness tax is highest compared to the year after. 
Table 2: Descriptive Statistics of Tax Aggressiveness 2013-2015

\begin{tabular}{|c|c|c|c|c|c|}
\hline No & Kode & Nama Perusahaan & $\begin{array}{l}\text { Tahun } \\
2013\end{array}$ & 2014 & 2015 \\
\hline 1 & AGII & Aneka Gas Industri Tbk. & 0,02178 & 0,06206 & 0,01089 \\
\hline 2 & ALDO & Alkindo Naratama Tbk. & 0,08054 & 0,07608 & 0,07633 \\
\hline 3 & AMFG & Asahimas Flat Glass Tbk. & $-0,00523$ & 0,01019 & 0,01278 \\
\hline 4 & APLI & Asiaplast Industries Tbk. & $-0,02509$ & $-0,01944$ & $-0,00537$ \\
\hline 5 & BTON & Betonjaya Manunggal Tbk. & 0,02267 & 0,01000 & 0,00630 \\
\hline 6 & CPIN & Charoen Pokphand Indonesia Tbk & 0,03596 & $-0,05332$ & $-0,01296$ \\
\hline 7 & DPNS & Duta Pertiwi Nusantara Tbk. & 0,23742 & 0,00478 & 0,00679 \\
\hline 9 & INTP & Indocement Tunggal Prakarsa $\mathrm{Tb}$ & 0,00480 & 0,02969 & 0,03151 \\
\hline 10 & JPFA & Japfa Comfeed Indonesia Tbk. & 0,01045 & 0,00656 & 0,03677 \\
\hline 11 & KDSI & Kedawung Setia Industrial Tbk. & 0,04217 & 0,04782 & 0,00065 \\
\hline 12 & LION & Lion Metal Works Tbk. & 0,01133 & 0,00629 & 0,00476 \\
\hline 13 & LMSH & Lionmesh Prima Tbk. & 0,10150 & 0,00270 & $-0,01177$ \\
\hline 14 & PICO & Pelangi Indah Canindo Tbk & 0,01606 & 0,01119 & 0,01065 \\
\hline 15 & SMBR & Semen Baturaja (Persero) Tbk. & 0,01519 & 0,03974 & 0,02990 \\
\hline 16 & SMCB & Holcim Indonesia Tbk. & $-0,00611$ & $-0,01700$ & $-0,00956$ \\
\hline 18 & SRSN & Indo Acidatama Tbk & 0,00543 & $-0,01132$ & $-0,00831$ \\
\hline 19 & TALF & Tunas Alfin Tbk. & $-0,00136$ & 0,01333 & 0,02899 \\
\hline 20 & TOTO & Surya Toto Indonesia Tbk. & $-0,02710$ & $-0,02747$ & $-0,02410$ \\
\hline 21 & TRST & Trias Sentosa Tbk. & 0,01192 & $-0,01389$ & $-0,00684$ \\
\hline 22 & ASII & Astra International Tbk. & 0,10336 & 0,09961 & 0,06463 \\
\hline 23 & AUTO & Astra Otoparts Tbk. & 0,05963 & 0,05594 & 0,01544 \\
\hline 24 & BATA & Sepatu Bata Tbk. & 0,01119 & $-0,00985$ & 0,13767 \\
\hline 25 & INDS & Indospring Tbk. & 0,03306 & 0,01581 & $-0,00127$ \\
\hline 26 & JECC & Jembo Cable Company Tbk. & $-0,00871$ & $-0,01205$ & $-0,01195$ \\
\hline 27 & KBLI & KMI Wire \& Cable Tbk. & $-0,02755$ & $-0,02680$ & $-0,01772$ \\
\hline 28 & KBLM & Kabelindo Murni Tbk. & $-0,00149$ & $-0,00204$ & $-0,02448$ \\
\hline 29 & NIPS & Nipress Tbk. & $-0,01409$ & $-0,00728$ & $-0,01049$ \\
\hline 30 & RICY & Ricky Putra Globalindo Tbk & 0,00018 & 0,00376 & 0,00306 \\
\hline 31 & SCCO & Supreme Cable Manufacturing & 0,00410 & $-0,00490$ & 0,01882 \\
\hline 32 & SMSM & Selamat Sempurna Tbk. & 0,10623 & 0,08935 & 0,09137 \\
\hline 33 & UNIT & Nusantara Inti Corpora Tbk & 0,00923 & 0,01269 & 0,00253 \\
\hline 34 & ADES & Akasha Wira International Tbk. & 0,08953 & $-0,01382$ & 0,01105 \\
\hline 37 & DLTA & Delta Djakarta Tbk. & 0,07371 & 0,08472 & 0,00747 \\
\hline 38 & DVLA & Darya-Varia Laboratoria Tbk. & 0,01192 & $-0,00726$ & $-0,00435$ \\
\hline 39 & GGRM & Gudang Garam Tbk. & 0,00366 & 0,01259 & 0,00366 \\
\hline 40 & HMSP & H.M. Sampoerna Tbk. & $-0,00097$ & 0,00485 & 0,00357 \\
\hline 41 & ICBP & Indofood CBP Sukses Makmur Tbk & $-0,00819$ & $-0,01296$ & $-0,01226$ \\
\hline 42 & INDF & Indofood Sukses Makmur Tbk. & 0,05747 & 0,05572 & 0,04658 \\
\hline 43 & KAEF & Kimia Farma Tbk. & 0,06164 & 0,05701 & 0,04536 \\
\hline 44 & KLBF & Kalbe Farma Tbk. & 0,15415 & 0,15478 & 0,15476 \\
\hline 45 & MERK & Merck Tbk. & $-0,02450$ & 0,02369 & $-0,04527$ \\
\hline 46 & MLBI & Multi Bintang Indonesia Tbk. & 0,25679 & 0,11412 & 0,17687 \\
\hline 47 & MYOR & Mayora Indah Tbk. & 0,04646 & 0,01733 & 0,08863 \\
\hline 48 & PYFA & Pyridam Farma Tbk & $-0,01773$ & $-0,01930$ & $-0,02406$ \\
\hline 49 & ROTI & Nippon Indosari Corpindo Tbk. & $-0,00402$ & 0,02774 & 0,02086 \\
\hline 50 & SIDO & Industri Jamu dan Farmasi Sido & 0,01228 & 0,05265 & 0,04792 \\
\hline 51 & SKBM & Sekar Bumi Tbk. & $-0,01027$ & 0,05781 & $-0,01113$ \\
\hline 52 & SKLT & Sekar Laut Tbk. & 0,01854 & 0,00510 & $-0,00672$ \\
\hline 53 & SSTP & Siantar Top Tbk. & $-0,00445$ & $-0,01258$ & $-0,00781$ \\
\hline 54 & SQBB & Taisho Pharmaceutical Indonesi & 0,00632 & $-0,00830$ & 0,00164 \\
\hline 55 & TCID & Mandom Indonesia Tbk. & $-0,02019$ & $-0,01958$ & 0,20632 \\
\hline 56 & TSPC & Tempo Scan Pacific Tbk. & 0,08521 & 0,08155 & 0,07052 \\
\hline 57 & ULTJ & Ultra Jaya Milk Industry \& Tra & $-0,01918$ & $-0,02605$ & $-0,00840$ \\
\hline 58 & UNVR & Unilever Indonesia Tbk. & 0,01218 & 0,01319 & 0,01382 \\
\hline Min & & & $-0,02755$ & $-0,05332$ & $-0,04527$ \\
\hline $\operatorname{Max}$ & & & 0,25679 & 0,15478 & 0,20632 \\
\hline Mean & & & 0,03040 & 0,01995 & 0,02250 \\
\hline
\end{tabular}

Source: company financial statements (data processed). 


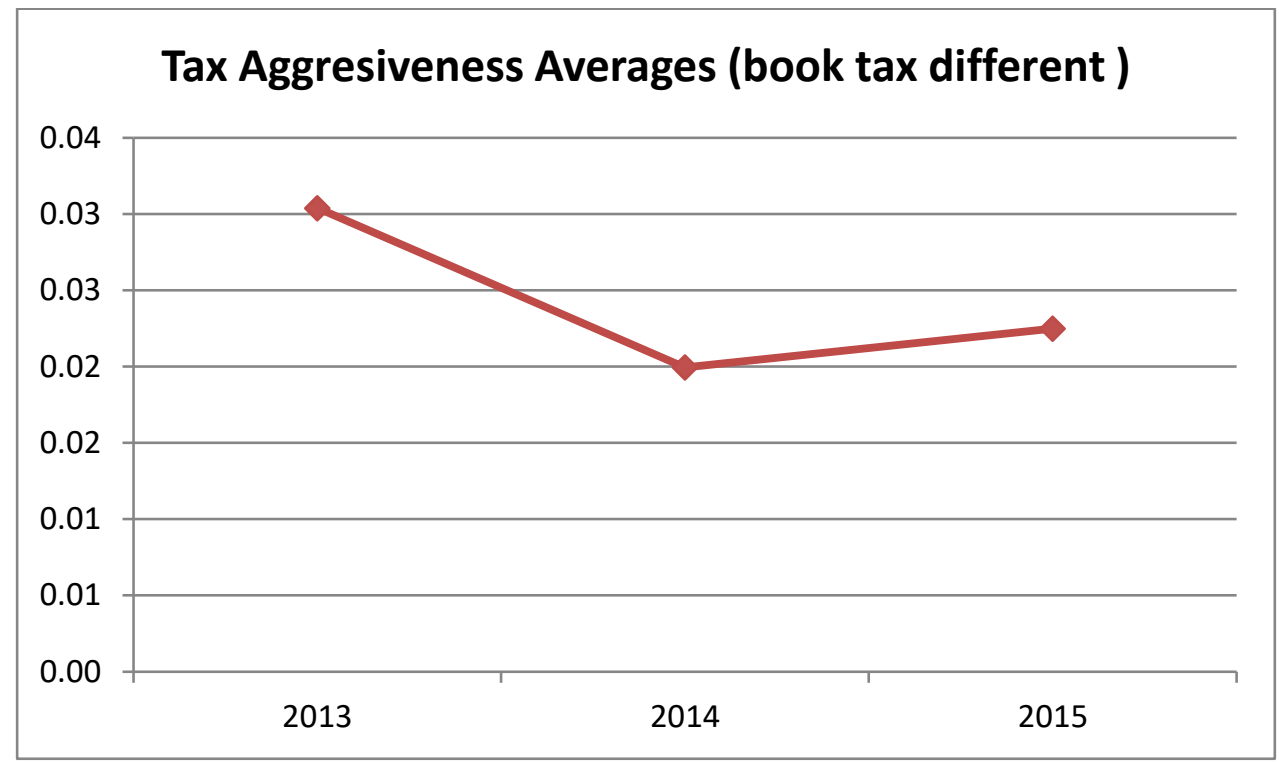

Fig. 2: Tax Aggresiveness Averages 2013-2015 Graphic.

Table 3: Descriptive Statistics

\begin{tabular}{|c|c|c|c|c|c|}
\hline & $\mathrm{N}$ & & & & \\
\hline The Number of Boards of Commissioners & 174 & 2 & 15 & 5 & 2.609 \\
\hline The Number of Boards of Director & 174 & 2 & 11 & 4 & 1,982 \\
\hline Tax Aggresiveness & 174 &,- 05332 & 25679 & ,0242824 & 04958023 \\
\hline Valid N (listwise) & 174 & & & & \\
\hline
\end{tabular}

Table 4: Coefficientsa

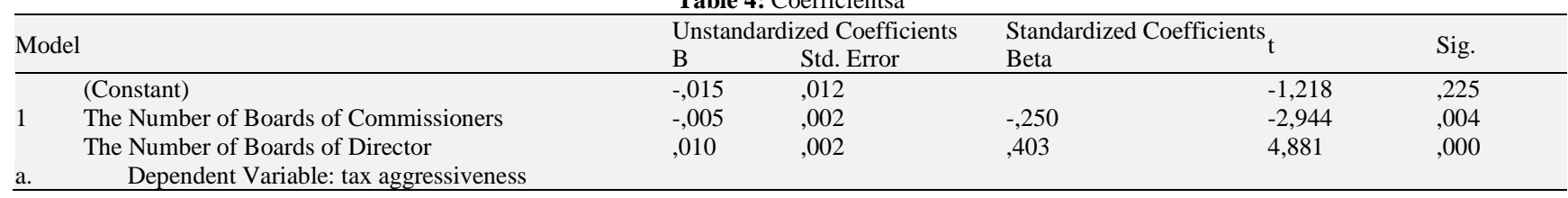

a) From Table 3. It can be seen that the lowest value of board size and board size is 2 and the highest value of board size is 15 while the highest value of the board size is 11 . The size of the board of commissioners has the mean value which is the sum of all data divided by with the amount of data that is equal to 5 and the size of the board of directors has an average of 4 . The standard deviation or deviation value of the mean value (size) of the board of commissioners and the size of the board of directors that is equal to 2,609 and 1,982 .

b) Dependent Variable (Y) used in this research is tax management with book tax different indicator. The sample used is 174 and has the lowest tax rate management -0.05332 and the highest value 0.25679 . Where the average value of tax management calculated from the total amount of data divided by the amount of data is equal to 0.0242824 . The standard deviation or deviation value of the mean value is 0.04958023 .

Based on the results of the data, obtained regression model as follows:

$\mathrm{Y}=\alpha+\beta_{1} \mathrm{X}_{1}+\beta_{2} \mathrm{X}_{2}$

$Y=-0,015-0,005 X_{1}+0,010 X_{2}$

From the regression equation can be explained as follows:

1) The constant value of $\alpha$ means that when the size of the board of commissioners (X1) and the size of the board of directors (X2) is absent or zero, the value of tax aggressiveness $(\mathrm{Y})$ is -0.015 .

2) The regression coefficient $\beta 1$ (board size of commissioner) that is equal to $-0,005$. The coefficient value of the board of commissioners size has a negative direction, meaning that if the size of the board of commissioners increases as much as one (assuming other variables remain), it will reduce the value of tax aggresiveness of 0.005 .

To determine whether there is any influence of the size of the board of commissioners against aggresiveness tax, first formulate the following hypothesis:

H0-1: $\beta_{-} 1=0$, the size of the board of commissioners has no effect on tax aggresiveness.

H1: $\beta \_1 \neq 0$, the size of the board of commissioners affects tax aggresiveness.

Based on these calculations, obtained the value of $\beta \_1 \neq 0$, ie $0.005 \neq 0$ then it can be concluded that Ho is rejected. The results of this hypothesis testing shows that the size of the board of commissioners affect the tax aggresiveness (BTD).

3) The regression coefficient $\beta 2$ (board size) is 0.010 . The coefficient size of the board of directors obtained has a positive direction, this indicates if the size of the board of directors increases by one (assuming other variables remain), the tax aggresiveness will increase by 0.010 .

To determine whether there is an effect of the size of the board of directors to tax aggresiveness, first formulate the following hypothesis:

H0-2: $\beta 2=0$, the size of the board of directors has no effect on tax aggresiveness.

$\mathrm{H} 2: 2 \neq 0$, the size of the board of directors affect tax aggresiveness.

Based on these calculations, obtained values $\beta \_2 \neq 0$, ie $0,010 \neq 0$ it can be concluded that Ho is rejected. The results of this hypothesis testing shows that the size of the board of directors affect the tax aggressiveness (BTD). 


\section{Coefficient of determination (R2)}

The coefficient of determination (R2) is used to find out how much independent variables explain the dependent variable. The coefficient of determination is between zero and one. If the coefficient of datermination $(\mathrm{R} 2)=0$ means there is no relationship between independent variables with dependent variable, vice versa for the coefficient of determination $(\mathrm{R} 2)=1$ then there is a perfect relationship. Used adjusted R2 as coefficient of determination if regression of free variable more than two.

Table 5: Coefficient of Determination Model Summary C, D Model R R Square ${ }^{\mathrm{b}}$ Adjusted R Square Std. Error of the Estimate

\begin{tabular}{llll}
\hline 1 & $, 628^{\mathrm{a}}, 395$ &, 380 &, 04385 \\
\hline
\end{tabular}

From the Table 5. View above the adjusted $\mathrm{R}$ square is 0,380 or $38 \%$ variable tax aggresiveness (Y) can be explained by Profitability variable, Debt Rate, Board size and Board of Directors. While the rest of $62 \%$ influenced by other variables that are not included in this study.One of the objectives of this research is to know the influence of corporate governance on tax aggresiveness. Corporate governance shows relationships between various stakeholders, both internal and external, that are useful in determining the strategic direction and overseeing the performance of the company. In the descriptive analysis can be seen most of the size of the board of commissioners and the size of the board of directors of the company each year did not increase. The results of the analysis show that the size of the board of commissioners and the size of the board of directors affect the tax aggresiveness. This is evidenced based on the coefficient value of each board size and board size of -0.005 and 0.010 , where the value is $\neq 0$.

The coefficient value of the board of commissioners size has a negative direction, meaning that if the size of the board of commissioners increases as much as one (assuming other variables remain), it will reduce the value of tax aggresiveness of 0.005 . While the coefficient value of board of directors that have got positive direction, this shows if the size of the board of directors increases by one (assuming other variables remain), then tax aggresiveness will rise by 0.010 . Then the results of this hypothesis testing shows that the size of the board of commissioners affect the tax aggresiveness (BTD).

This is in accordance with the statement of Zulkarnaen (2015) that the increase of commissioners will cause the company performance will be more effective, so the company will do things that are considered important in order to achieve an effectiveness in the company's activities including in the determination of policies related to tax aggresiveness. The size of the board of commissioners and the size of the board of directors each affect the tax aggresiveness. Then it can be said corporate governance effect on tax aggresiveness. This can happen because corporate governance within a company can prevent a company from engaging in aggressive business in tax management. Companies are more cautious as they relate to tax-related rules.

The results of this study are in accordance with the statement of Zulkarnaen (2015) that the higher board size will enable them to ensure that management actions are in line with the shareholders' interests of tax management so that the tax payable borne by the company is low. A low tax debt will provide a higher return for shareholders.

However, this result is inversely related to the research conducted by Minnick and Noga (2010) which found no significant relationship between the implementation of corporate governance mechanism with corporate tax management. While Sari (2010), in his research, found that the implementation of corporate governance can limit the aggressive tax action of companies that make tax payments become greater.

\section{References}

[1] Armstrong, Christopher S., Jennifer L. Blouin, and David F. Larcker. (2012). the Incentives for Tax Planning. Journal of Accounting and Economics53.hlm. 391-411. https://doi.org/10.1016/j.jacceco.2011.04.001.

[2] Desai, M. A., Dharmapala, D. (2006). Corporate tax avoidance and high powered incentives. Journal of Financial Economics, 79(1), 145-179. https://doi.org/10.1016/j.jfineco.2005.02.002.

[3] Fuest, C and N. Riedel (2009). Tax Evasion and Tax Avoidance in Developing Countries: The Role of International Profit Shifting Paper Prepared for the World Bank Conference "The Dynamics of Illicit Flows from Developing Countries" on September 14-15, 2009.

[4] Frank, M., Lynch, L., \& Rego, S. (2012). Tax reporting aggressiveness and itsrelation to aggressive financial reporting. The Accounting Review 84, hlm. 467-496

[5] Hanlon, Michelle, and Joel Slemrod. 2009. "What does tax aggressiveness signal? Evidence from stock price reactions to news abou tax shelter involvement." Journal of Public Economics, 93(1-2): 126-141. https://doi.org/10.1016/j.jpubeco.2008.09.004.

[6] Irawan, H.P. \& Farahmita, A. (2012). Pengaruh Kompensasi Manajemen dan Corporate GovernanceTerhadap Manajemen Pajak Perusahaan, Jurnal Ekonomi dan Bisinis, Fakultas Ekonomi, Universitas Indonesia, Depok

[7] Kristiyono, Y. (2015). Tahun Lalu Jumlah Kasus Pajak Meningkat 280 Persen. [Online]. Diakses darihttp://www.cnnindonesia.com

[8] Shleifer, A., \& Vishny, R. W. (1997). A survey of corporate governance. The journal of finance, 52(2), 737-783. https://doi.org/10.1111/i.1540-6261.1997.tb04820.x.

[9] Sudiarta. I Wayan. 2016. Panama Papers dan Penghindaran Pajak, https://www.cnnindonesia.com/ekonomi/20160412112445-79123307/panama-papers-dan-praktik-penghindaran-pajak/

[10] Mangoting. Yenni. 1999. Tax Planning : sebuah Pengantar sebagai Alternatif Meminimalkan Pajak, Jurnal Akuntansi dan Keuangan, Vol. 1 No. 1

[11] Minnick, K. \& Noga, T. (2010). Do Corporate Governance Characteristics Influence Tax Management?. Journal of Corporate Finance, $16, \quad \mathrm{hlm}$. 703-718 https://doi.org/10.1016/j.jcorpfin.2010.08.005.

[12] Noor, R., Fadzillah, N. S. M., \& Mastuki, N. A. (2010). Corporate Tax Planning: A Study on Corporate Effective Tax Rates of Malaysian Listed Companies.International Journal of Trade, Economics $\begin{array}{lll}\text { and } & \text { Finance.1 } & \text { (2).hlm. }\end{array}$ https://doi.org/10.7763/IJTEF.2010.V1.34.

[13] Prawira, Ida Farida Adi. 2016. Organizational Culture, Law Enforcement, and Indonesian Tax Revenues, International Journal of Accounting and Economics Studies, 4(2), 152-156 https://doi.org/10.14419/ijaes.v4i2.6706.

[14] Rashid, M. Noor. R. Mastuki, N. A. Bardai, B. (2015).Longitudinal Study of Corporate Tax Planning:Analysis on Companies' Tax Expense and Financial Ratios. Pertanika Journal, Sosial Sciences \& Humanities 23, hlm. 109-120

[15] Wahab, N.S. Abdul.., \& Holland, K. 2012. Tax Planning, Corporate Governance and Equity Value, The British Accounting Review, 44, 111-124. https://doi.org/10.1016/j.bar.2012.03.005.

[16] Zulkarnaen, Novriansyah. (2015). Pengaruh Good Corporate Governance terhadap Manajemen Pajak. Esensi Jurnal Bisnis dan Manajemen, 5 (1) 